\title{
Nucleotide Sequence of the Immunity and Lysis Region of the ColE9-J Plasmid
}

\author{
By RICHARD JAMES, ${ }^{1 *}$ MARK JARVIS ${ }^{2}$ AND DICK F. BARKER ${ }^{2}$ \\ ${ }^{1}$ School of Biological Sciences, University of East Anglia, Norwich NR4 7TJ, UK \\ ${ }^{2}$ Plant Breeding Institute, Cambridge CB2 2LQ,UK
}

(Received 5 December 1986; revised 26 January 1987)

\begin{abstract}
We have determined the nucleotide sequence of a $1500 \mathrm{bp}$ fragment of the ColE9-J plasmid which encodes colicin E9 immunity and colicin E5 immunity and contains two lys genes. Open reading frames corresponding to the four genes have been located and their position confirmed by transposon mutagenesis of sub-clones of the ColE9-J plasmid. The E9imm gene shows $69 \%$ homology at both the nucleotide and the amino acid level to the previously sequenced E2imm gene. The E5imm gene shows little homology to any other E colicin immunity gene which has been sequenced. The lys gene distal to the $3^{\prime}$ end of the E5imm gene shows considerable sequence homology to all other previously sequenced E colicin lys genes. The lys gene distal to the $3^{\prime}$ end of the E9imm gene is identical to the pColE2 and pColE3 lys genes for the first 59 nucleotides but encodes a much smaller gene product than any other lys gene which has been sequenced. The two lys genes sequenced here are exceptions to Shepherd's rule concerning the number of RNY codons in the three possible reading frames.
\end{abstract}

\section{INTRODUCTION}

The E colicins are a group of plasmid-encoded antibacterial proteins which use the same cellsurface receptor, the product of the Escherichia coli chromosomal gene $b t u B$, to bind to sensitive cells (Di Masi et al., 1973). This group has been subdivided into colicins E1 to E9 on the basis of immunity tests (Watson et al., 1981; Cooper \& James, 1984). The killing activity of several of the E colicins has been identified (Konisky, 1982). Each E colicin plasmid codes for the production of a specific immunity protein, which protects colicin-producing cells against colicin of the same immunity type. E. coli $\mathrm{K} 12$ strains carrying an E colicin plasmid are sensitive to mitomycin $\mathrm{C}$ (MC) compared to plasmid-free isogenic strains, due to the induction of a plasmid-coded lysis gene (lys) which is involved in colicin release from the producing cell. Transposon mutagenesis of the ColE3-CA38 plasmid has demonstrated that the colicin E3 structural gene $(\mathrm{ceaC})$ and the lys gene (celC) are transcribed from a common SOS promoter located proximal to the colicin E3 gene whilst the ColE3imm gene (ceiC), which is located between these two genes, has its own promoter (Chak \& James, 1984; Jakes \& Zinder, 1984). A similar genetic organization has been observed for the colicin E2 operon (Cole et al., 1985).

We have identified a second unrelated immunity gene, to colicin E8 (ceiH), located distal to the ColE3imm gene and proximal to the lys gene celH (Chak \& James, 1984), the nucleotide sequence of which has subsequently been reported (Lau et al., 1984). Comparison of the nucleotide sequence of the ColE8imm gene with that of the ColE2imm gene has revealed marked homology, which has led to the suggestion that the ColE3-CA38 plasmid may 'represent a unique case of a plasmid caught in the evolutionary process' (Lau et al., 1984). The subsequent observation of the presence of two immunity genes in the ColE6-CT14 plasmid (Lawrence,

\footnotetext{
Abbreviations: MC, mitomycin C; ORF, open reading frame; RNY codon, a codon consisting of a purine followed by any base and then by a pyrimidine.
} 
1984) and in the ColE9-J plasmid (Chak \& James, 1986) has suggested that the presence of two immunity genes on an E colicin plasmid may be a fairly common occurrence. Our previous characterization of the ColE9-J plasmid was particularly interesting in that as well as the presence of two immunity genes, to colicin E5 and colicin E9, it also showed for the first time with an E colicin plasmid the presence of two functional lys genes. Here we present a more detailed analysis of the functional organization of the ColE9 operon and report the nucleotide sequence of a $1500 \mathrm{bp}$ region of the ColE9-J plasmid which includes the two immunity genes and the two lys genes.

\section{METHODS}

Plasmids. The ColE9-J plasmid (Cooper \& James, 1984), and the recombinant plasmids pKC64, pKC65, pKC67 and pKC124 (Chak \& James, 1986) have been previously described. Plasmid pRJ 261 is the $2.42 \mathrm{~kb} \mathrm{ClaI}$ fragment of pKC64 ligated into the Clal site of pBR322 in the opposite orientation to that found in plasmid pKC64. Plasmids were prepared by a modification of the method of Birnboim \& Doly (1979).

Bacterial strains and media. E. coli $\mathrm{W} 3110$ was used as the host strain for all the recombinant plasmids. Cultures containing recombinant plasmids were grown in LB broth, or on plates of LB agar (Miller, 1972), containing ampicillin $(100 \mu \mathrm{g} \mathrm{ml}-1)$.

Enzymes and reagents. Restriction enzymes and T4 DNA ligase were purchased from Anglian Biotechnology, Gibco-BRL or Pharmacia. MC (Sigma) was used as previously described to test the MC sensitivity of cultures containing recombinant plasmids (Chak \& James, 1984).

Colicin production and immunity tests. These were done as previously described (Cooper \& James, 1984).

Plasmid restriction, ligation, transformation and electrophoresis. Digestion of DNA with restriction endonucleases, ligation of DNA fragments and transformation of competent cells were done as described by Maniatis et al. (1982). Electrophoresis of restriction fragments was performed as previously described (Chak \& James, 1984).

Transposon mutagenesis. Transposon mutagenesis with $\mathrm{Tn} 1000$ was performed as previously described (Chak \& James, 1984). Transposon insertion sites were mapped by isolating plasmid DNA and restricting separately with EcoRI, BamHI or Hind III (Guyer, 1978).

Nucleotide sequencing. The nucleotide sequence of $1500 \mathrm{bp}$ of the $2.42 \mathrm{~kb}$ ClaI fragment of plasmid pKC124 was determined by the method of Maxam \& Gilbert (1980) with the modifications reported by Barker et al. (1983). $\left[\gamma^{32} \mathrm{P}\right] \mathrm{ATP}$ was obtained from New England Nuclear. All chemicals used in the DNA sequencing reactions were obtained from the recommended suppliers (Maxam \& Gilbert, 1980). Plasmid pKC124 is identical to pKC64 except that the vector was pKC87 (Chak \& James, 1985), in which the polylinker sequence facilitates nucleotide sequencing. The nucleotide sequence of the immunity and lysis genes present in this $1500 \mathrm{bp}$ was analysed using a series of computer programs, written for the BBC model B microcomputer by one of us (R. J.), which determines the GC ratio and analyses the distribution of RNY codons in all three possible reading frames.

\section{RESULTS AND DISCUSSION}

\section{Functional characterization of the ColE9 operon}

A restriction map of the ColE9 operon, with a provisional localization of the relevant genes, has previously been reported (Chak \& James, 1986). The $2.42 \mathrm{~kb}$ Cla I fragment of the ColE9 operon encodes E9imm, E5imm and two lys genes. Cloning of this fragment into the ClaI site of pBR322 gave transformants whose phenotype depended upon the orientation of the insert (Fig. 1). In one orientation the recombinant plasmid, pRJ261, encoded E5imm alone, whereas in the other orientation the recombinant plasmid, pKC64, encoded both E5imm and E9imm. This result can be explained in the light of the direction of transcription of the tet promoter of pBR322 with respect to the insert, and implies that the E5imm gene present in the $2.42 \mathrm{~kb} \mathrm{ClaI}$ fragment must have its own promoter, whilst the E9imm gene is dependent upon the tet promoter of the vector for its transcription. The two lys genes present in the ColE9 operon were both dependent for their transcription on an SOS promoter located proximal to the colicin E9 structural gene (Chak \& James, 1986). Although the two lys genes were shown to be located on separate EcoRI fragments of the ColE9-J plasmid, their position was inferred largely by analogy with that of the lys genes of other $\mathrm{E}$ colicin plasmids. In an attempt to locate the two lys genes more precisely we performed transposon mutagenesis with recombinant plasmid pKC67. The presence of two phenotypically identical lys genes on one plasmid causes a problem with nomenclature. Presumably the two lys genes should be called E9lys (celI) and E5lys (celE), but which is which? 

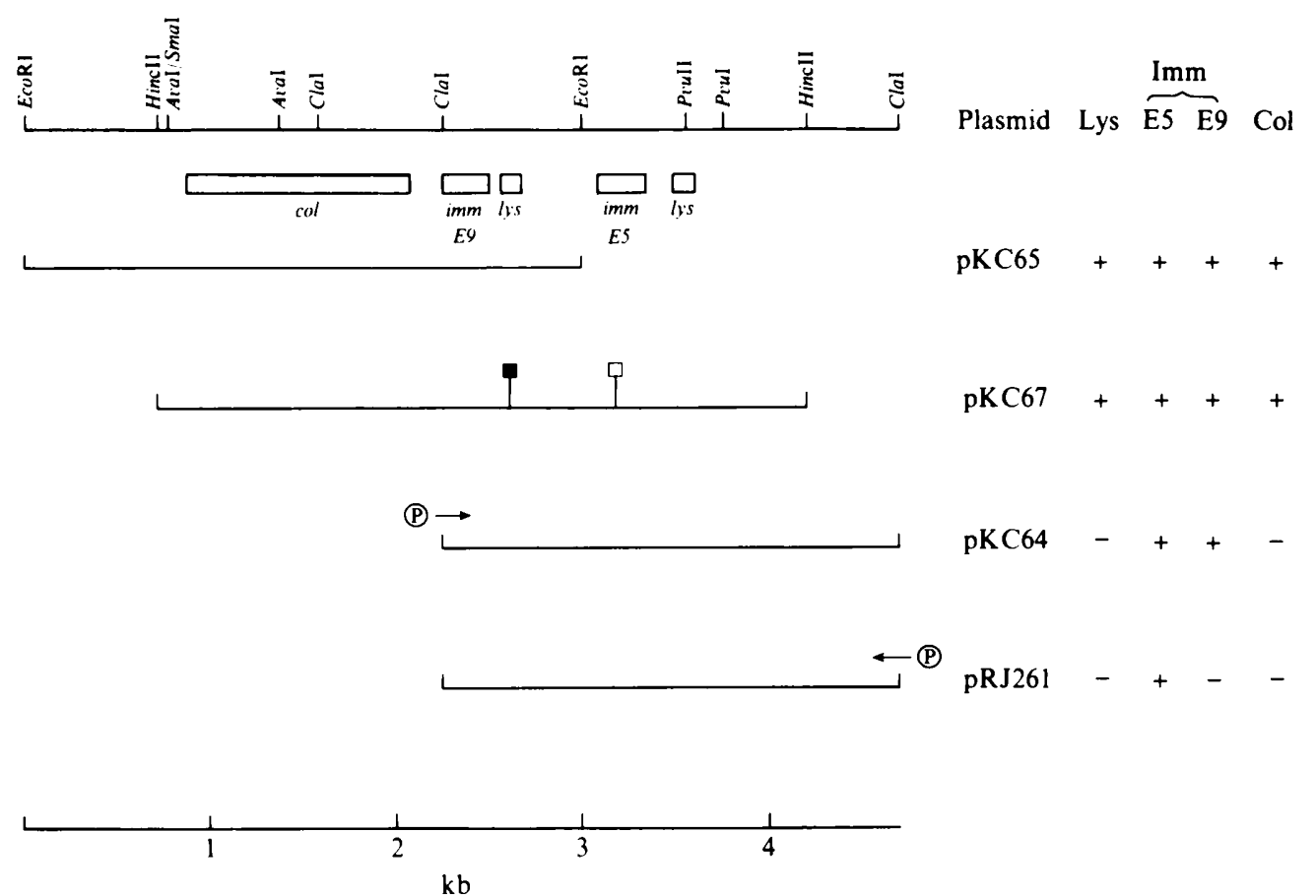

Fig. 1. Sub-cloning and transposon mutagenesis of the ColE9-J plasmid. The restriction fragments present in the plasmids listed are indicated (for clarity the vector sequences are not shown), together with the phenotypes conferred. The Tnl000 transposon insert sites in plasmids pRJ183 ( $\square$ ) and pRJ185 $(\square)$ are indicated. The arrows indicate the direction of transcription of the tet promoter in plasmids pKC64 and pRJ261.

In this paper we will refer to the lys gene which is proximal to the $5^{\prime}$ end of the ESimm gene as being the E9lys gene, and that which is distal to the $3^{\prime}$ end of the E5imm gene as being the E5lys gene.

After Tn 1000 mutagenesis of plasmid pKC67 several transconjugant colonies were observed which exhibited small zones when tested for colicin E9 production. We had observed a similar phenomenon in earlier work with the ColE3-CA38 (Chak \& James, 1984) and the ColE8-J plasmids (Lawrence \& James, 1984) and had demonstrated that transposon inserts which showed this phenotype were located in the lys genes of these plasmids. The Tn 1000 insert sites in pKC67 were mapped in six of these transconjugants and were found to be located in a single cluster in a region between 400 and 300 bp to the left of the EcoRI site in plasmid pKC67. This group of transposon inserts, characterized by plasmid pRJ183 (Fig. 1), exhibited immunity to both colicin E5 and E9. A second group of four interesting transconjugants, characterized by plasmid pRJ185, were identified due to their loss of immunity to colicin E5. Their Tn 1000 insert sites were located in a region within between 100 and $350 \mathrm{bp}$ to the right of the EcoRI site of pKC67. E. coli W3110(pRJ185) was as sensitive to MC as was $E$. coli W/3110(pKC67), whilst $E$. coli $\mathrm{W} 3110$ (pRJ183) was MC resistant (Fig. 2). These results confirm the presence of the E9lys gene located in the right hand $400 \mathrm{bp}$ of the EcoRI fragment of pKC65. In previous experiments with $\mathrm{Tn} 1000$ all inserts distal to the SOS promoter and proximal to a lys gene have prevented expression of the lys gene (Chak \& James, 1984, 1986). Since the Tn 1000 insert in pRJ185 was proximal to the E5lys gene but did not affect MC sensitivity this suggests a dominant role of the E9lys gene in MC sensitivity. 


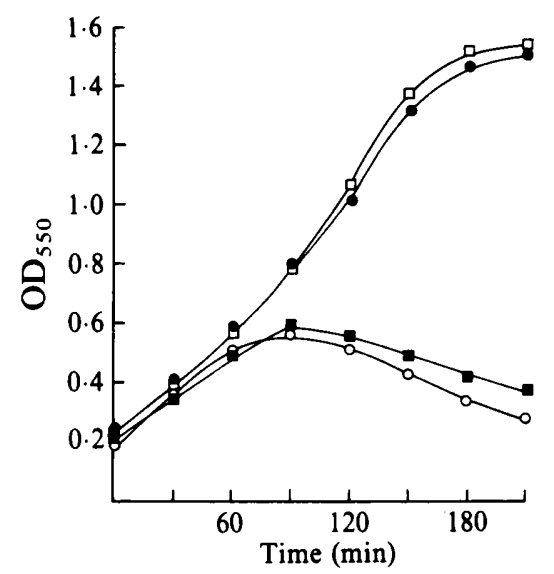

Fig. 2. MC sensitivity phenotypes conferred by plasmid pKC67 carrying Tn 1000 inserts. At time zero, MC $\left(0.5 \mu \mathrm{g} \mathrm{ml}^{-1}\right)$ was added to exponentially growing cultures of $E$. coli W3110 carrying plasmid pBR322 ( $\square)$, pKC67 ( $\square)$, pRJ183(O) or pRJ185(O). This experiment was repeated three times, and in each case the results were comparable to those shown. For the sake of clarity the control curves, which were essentially identical for all four cultures, are omitted.

\section{Nucleotide sequencing}

The $2.42 \mathrm{~kb}$ Cla I fragment of the ColE9-J plasmid encodes colicin E9 immunity and colicin E5 immunity and also contains the genetic information for two lys genes. Starting from the lefthand ClaI site we have sequenced 1500 bp of DNA (Fig. 3). From our previous sub-cloning experiments, the first $720 \mathrm{bp}$ of this sequence, from the ClaI site to the EcoRI site, must encode the E9imm gene and the E9lys gene, whilst the sequence from the EcoRI site to the PvuI site must encode the E5imm gene and the E5lys gene. Very few open reading frames (ORFs) of any significant size were found in this $1500 \mathrm{bp}$ sequence.

The 720 bp ClaI-EcoRI fragment. A large ORF (bases 10 to 270) encodes a protein of 86 amino acids. Since a transposon insert located 600 bp proximal to the EcoRI site inactivates colicin E9 immunity (Chak \& James, 1986), we believe that this ORF is the E9imm gene. The absence of a promoter proximal to the coding region of the E9imm gene is also in agreement with our findings that transcription of this immunity gene is dependent upon the tet promoter when the $2.42 \mathrm{~kb}$ ClaI fragment is cloned into pBR322. A comparison of the nucleotide sequence of the presumptive E9imm gene with the three $\mathrm{E}$ colicin immunity genes which have previously been sequenced reveals a marked homology between the E9imm gene and the E2imm gene (Fig. 4). The degree of homology ( $69 \%$ at both the nucleotide and the amino acid level) is even higher than that previously reported for the E2imm and the E8imm genes (Lau et al., 1984). In contrast, the homology between the E9imm gene and the E3imm gene is $37 \%$ at the nucleotide level and only $7 \%$ at the amino acid level (data not shown).

Several ORFs are located distal to the $3^{\prime}$ end of the E9imm gene: bases 274 to 399, 295 to 399, 299 to 412 and 332 to 412 . Our Tn 1000 mutagenesis data are consistent with any of these ORFs encoding the E9lys gene but, based on a comparison with the nucleotide sequence of other lys genes (Toba et al., 1986), we believe that the latter ORF corresponds to the E9lys gene. This presumptive E9lys gene, unlike the other three ORFs, is also preceded by a potential ribosomebinding site sequence ( $5^{\prime}$-AGGAG) starting at base 321 (Shine \& Dalgarno, 1974). As has been pointed out by Cole et al. (1985) and by Toba et al. (1986), there is considerable sequence homology between the lys genes encoded by the ColE2-P9, ColE3-CA38, CloDF13 and the ColE1 plasmids; indeed the nucleotide sequences of the pColE2 and the pColE3 lys genes are identical. These two lysis proteins consist of 47 amino acids and have an $M_{\mathrm{r}}$ of 4854 . The first 59 nucleotides, and the first 19 amino acids, of the presumptive E9lys gene are identical to those 
MetGluLeuLysHi s SerIleSerAspTyrThrGluAlaGluPheLeuGlnLeuValThrThrIle GTAAGTAAATGGAACTGAAGCATAGCATTAGTGATTATACAGAAGCTGAATTTTTACAACTTGTAACAACAATT

CysAsnalaAsnThrSerSerGluGluGluLeuValLysLeuValThrHis PheGluGlulletThrGluHi sPro TGTAATGCGAACACTTCCAGTGAAGAAGAACTGGTTAAATTGGTTACACACTTTGAGGAAATGACTGAGCACCCT

SerGlySerAspleu AGTGGTAGTGATTTAATATATTACCCAAAAGAAGGTGATGATGACTCACCTTCAGGTATTGTAAACACAGTAAAA

•

GInTrpArgAlaAlaAsnGlyLysSerGlyPheLysGlnGly***

CAATGGCGAGCCGCTAACGGTAAGTCAGGATTTAAACAGGGCTAAATATGAGTGCCGGTTGTTIAAGGATGAAT

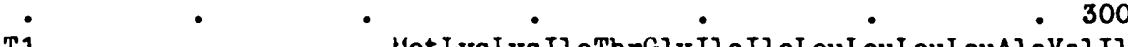
GGCTGGCATCTTTCACAACAGGATCG Het Lys IleThrGly IleIleLeuLeuLeuLeuAlaValIle

GGCTGGCATTCTITCACAACAAGGAGTCGTIATGAAAAAAATAACAGGGATTATTTTATTGCTTCTTGCAGTCAT

IleLeuSerAlaTrpGlySerLys ProLysThr***

TATTCTGTCTGCATGGGGTCTAAGCCGAAAACCTAGAAAATTCCGTAACCAAAGCCAGTAATMGACAGATTTGC

ATGACGMTGAATAGGTGACGGTTATGTGACGAAATCTGATGCAGAAATCGTTGTTCAGTGACAGTCACTCAAT

• • • • • 525

CGGTCGTTTATGTGACAACCCACGCCGTTACEGGTCGCGGAAAAATCCAGGTTTCCGGCCTGGAACCCCGAAATG

ATCCAGCAACAGTGATGGTTCTCCTGGTAATATGTTGTTGTCAATGATCGTACTGGTGAGGTACTCAGATTA

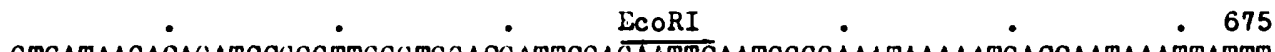

GTGATAAGACAGATCCGGGTTGGTGGACGATTCGAGAATTCAATGGGAAATAAAAATGACCAATAAATTATTT

-35 -10 HetLysLeuSerPro

GAACATACGGTGTTATATGATAGTGGTGATGCCT TTTTGAATTAAAAGGAAATGCTTCTATGAAGTTATCACCA

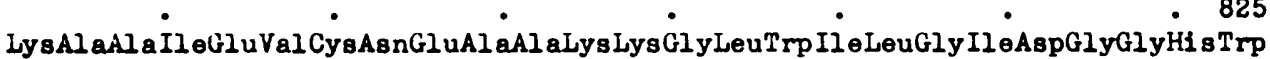
AAAGCTGCAATAGAAGTTTGTAATGAAGCAGCGAAAAAAGGCTTATGGATTTTGGGCATTGATGGTGGGCATTGG

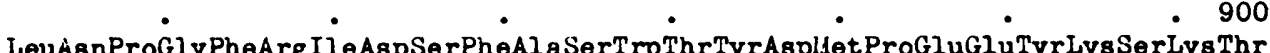
CTGAATCCTGGATTCAGGATAGATAGTTCAGCATCATGGACATATGATATGCCGGAGGAATACAAATCAAAAACC

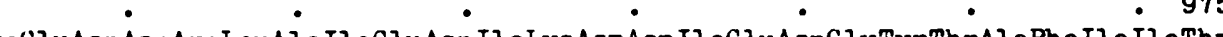

ProGluAsnAsnArgLeuAlaIleGluAsn IleLysAspAspIleGluAsnGly TyrThrAlaPheIleIleThr CCTGAAAATATAGATTGGC'PATTGAAAATATMAAAGATGATATTGAGAATGGATACACTGCTTTCATTATCACG

LeuLysblet***

TTAAAGATGTAATAGTGTTATAGAATTTATGTTTCATGGATGATTTCAACCTTTGGATTTCAGGTTTTTATGG

- 1050

T • • • • 1125

Het Lys Lys I leThrGly IleIleLeuLeuLeuLeuAlaAla ATGAACGCCTGAGTTCATATATACAAGGAACAGTATGAAAAAAATAACAGGGATTATTTTATTGCTTCTTGCAGC

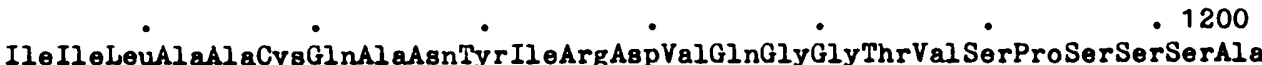
CATTATTCTTGCTGCATGTCAGGCAAACTATATCCGCGATGTTCAGGGGGGGACTGTATCCCCGTCATCCTCAGC

GluLeuThrGlyLeuAlaThrGln***

1275

TGAACTGACCGGATTAGCAACGCAGTAACCCGAAATCCTCTTTGACAAAAACAAAGCGTGTCAGGCTGATTCTGA

•

TGCGCTTTTTTTTGAATGTCACAAAAGTTCCATGTGGGAGATGGGATCTAAAATCCCTGTGCAGAACCTTCCA

TCCGGTGGOAAAAACTTGTCATTTTGACCTGTTCGCCATTCGAAACGGTCGAAACCGATCGCGCATCGCTTTCG

Fig. 3. Nucleotide sequence of $1500 \mathrm{bp}$ of the $2.42 \mathrm{~kb}$ Clal fragment of plasmid pKC124. The deduced primary sequence of the products of E9imm, E5imm and the two lys genes are shown above the nucleotide sequence. The presumptive promoter sequences $(-35$ and -10$)$ located proximal to the $5^{\prime}$ end of the E5imm gene, and the transcription terminators, T1, T2 and T3, are indicated, as are the restriction sites for $E c o$ RI and PvuI. 
Met Glu Leu Lys His Ser Ile Ser Asp Tyr Thr Glu Ala Glu Phe Leu Gin ATG GAA CTG AAG CAT AGC ATT AGT GAT TAT ACA GAA GCT GAA TTT TTA CAA

E9imm $* * * * * * * * * \dot{*} * \mathrm{~A} * * * * * \mathrm{~T} * \dot{*} * * * * * * * * * \dot{*} * * \mathrm{C} * * \mathrm{G} * * * * * * * * * * \mathrm{C} * \mathrm{G} \mathrm{G} * \mathrm{G}$ $\mathrm{E} 2 \mathrm{imm}$ Glu

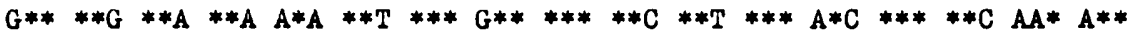

E8imm Lys GIy

Thr

Lys Lys

Leu Val Thr Thr Ile Cys Asn Ala Asn Thr Ser Ser Glu Glu Glu Leu Val CTT GTA ACA ACA ATT TGT AAT GCG AAC ACT TCC AGT GAA GAA GAA CTG GTT

E9imm

\begin{tabular}{|c|c|c|c|c|c|c|c|c|c|c|c|c|c|c|c|c|c|}
\hline & & & 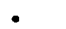 & & & $\bullet$ & & & • & & & & & & & • & \\
\hline ** & $* * *$ & $\begin{array}{l}* A * \\
\text { Lys }\end{array}$ & $\begin{array}{l}* A * \\
\text { Lys }\end{array}$ & $* * A$ & $* * *$ & $\begin{array}{l}* G A \\
\text { Arg }\end{array}$ & $\mathrm{C} * \mathrm{~T}$ & $\begin{array}{l}\mathrm{G} * \mathrm{~A} \\
\mathrm{Glu}\end{array}$ & $\begin{array}{l}\text { GG* } \\
\text { Gly }\end{array}$ & $\begin{array}{l}\mathrm{G} * \mathrm{~T} \\
\mathrm{Ala}\end{array}$ & $\begin{array}{l}* \mathrm{C} * \\
\text { Thr }\end{array}$ & $* * *$ & $* * 0$ & $\begin{array}{l}* * T \\
\text { Asp }\end{array}$ & $\begin{array}{l}\text { GAC } \\
\text { Asp }\end{array}$ & $\begin{array}{l}\mathrm{AA} \\
\mathrm{Asr}\end{array}$ & $\mathrm{E} 2 \mathrm{imm}$ \\
\hline * & $\begin{array}{l}A * T \\
I I_{e}\end{array}$ & GA* & $\begin{array}{l}\text { GAC } \\
\text { Ly } 8\end{array}$ & $* * C$ & $\begin{array}{l}\text { ATC } \\
\text { Ile }\end{array}$ & $* * *$ & $\begin{array}{l}\text { TGT } \\
\text { Cys }\end{array}$ & $\begin{array}{l}G * A \\
G \perp u\end{array}$ & $\begin{array}{l}\text { GG* } \\
\text { Gly }\end{array}$ & $\begin{array}{l}\text { GAT } \\
\text { Asp }\end{array}$ & & $* * *$ & $\begin{array}{l}A * * \\
L y 8\end{array}$ & $\begin{array}{l}A * * \\
L y 8\end{array}$ & $\begin{array}{l}* A * \\
\text { Glu }\end{array}$ & ${ }_{A B}^{* A}$ & \\
\hline
\end{tabular}

Lys Leu Val Thr His Phe Glu Glu Let Thr Glu His Pro Ser Gly Ser Asp AAA TTG GTT ACA CAC TTT GAG GAA ATG ACT GAG CAC CCT AGT GGT AGT GAT

E9imm

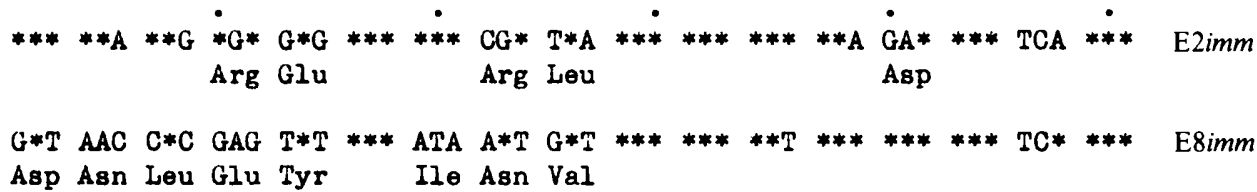
Leu Ile Tyr Tyr Pro Lys Glu Gly Asp Asp Asp Ser Pro Ser Gly Ile Val TTA ATA TAT TAC CCA AAA GAA GGT GAT GAT GAC TCA CCT TCA GGT ATT OTA

E9imm

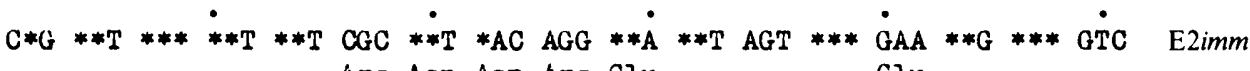
Arg Asp Asp Arg Glu Glu

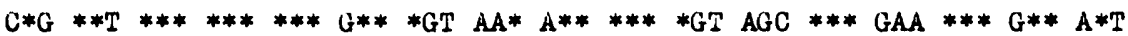

E8imm Glu Gly Asn Asn Gly Glu Val Ile

Asn Thr Val Lys Gln Irp Arg Ala Ala Asn Gly Lys Ser Gly Phe Lys Gln AAC ACA GTA AAA CAA TGG OGA GCC GCT AAC GGT AAG TCA GGA TTT AAA CAG

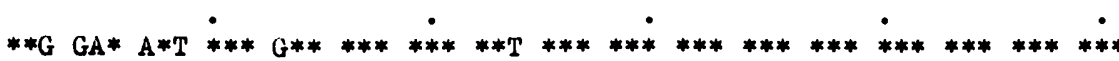

GIy

GGC E9imm

$* * * \quad \mathrm{E} 2 \mathrm{imm}$

\section{*** E8imm}

Fig. 4. Homology between $\mathrm{E}$ colicin immunity genes. The nucleotide and amino acid sequence of the E9imm gene is shown in full. Where the nucleotide sequence of the E2imm and E8imm genes is identical to that of the E9imm gene, this is indicated by an asterisk. The amino acid sequence of the E2imm and E8imm genes is only shown when it differs from that of the E9imm gene. 


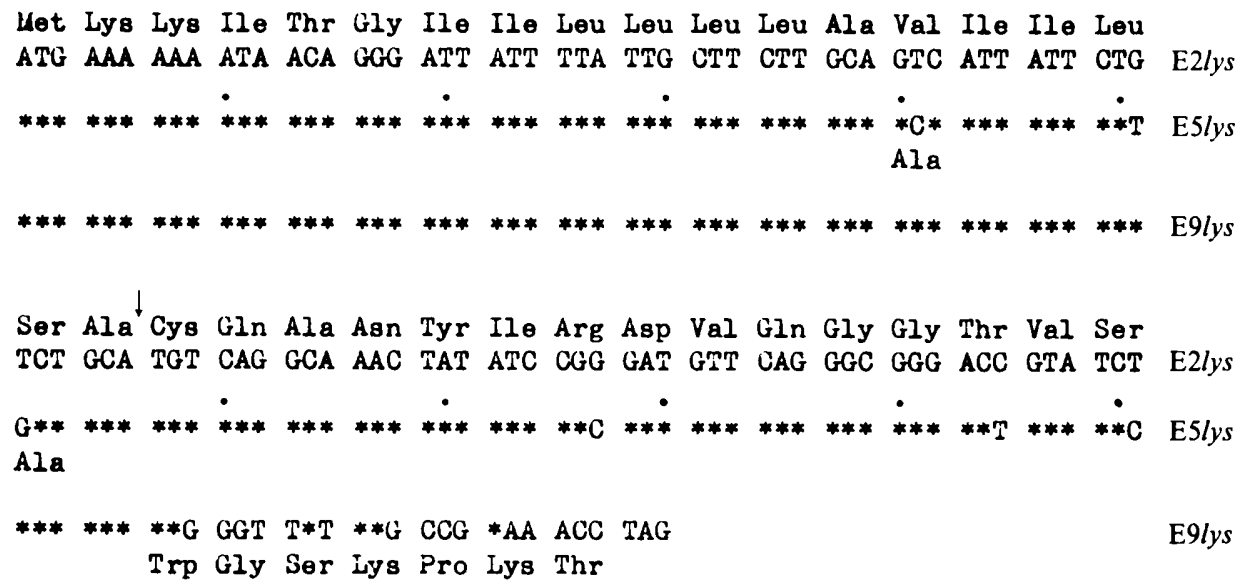

Pro Ser Ser Thr Ala Glu Val Thr Gly Leu Ala Thr Gln

CCG TCA TCA ACA GCT GAA GMG ACC GGA TTA GCA ACG CAG TAA E2lys

$* * * * * * * * \mathrm{C} \dot{\mathrm{T} * * * * * * * * \mathrm{C} * * * * * * * * * * \dot{*} * * * * * * * * * \dot{*} * * \text { Eslys }}$

Ser Leu

Fig. 5. Homology between E colicin lysis genes. The nucleotide and amino acid sequence of the E2lys gene is shown in full. Where the nucleotide sequence of the E5lys (the lys gene located distal to the 3' end of the E5imm gene on the ColE9-J plasmid) and E9lys genes is identical to that of the E2lys gene, this is indicated by an asterisk. The amino acid sequence of the E5lys and E9lys genes is only shown when it differs from that of the E2lys gene. The presumptive cleavage site of the signal sequences of the E2lys and E5lys genes is indicated by an arrow.

found in the ColE2 and ColE3 lys genes, but the remainder of the presumptive E9lys gene is very different, consisting of only 26 amino acids in total (Fig. 5).

The non-coding region of DNA located distal to the $3^{\prime}$ end of the E9imm gene and proximal to the $5^{\prime}$ end of the E9lys gene is virtually identical (58 of 60 bases) to a similar region located between the $3^{\prime}$ end of the E2imm gene and the $5^{\prime}$ end of the lys gene found on the ColE2-P9 plasmid, and to a region located between the 3' end of the E8imm gene and the $5^{\prime}$ end of the lys gene found on the ColE3-CA38 plasmid. As has been pointed out for this region of the ColE2-P9 plasmid (Cole et al., 1985) and of the ColE3-CA38 plasmid (Lau et al., 1984), the sequence from base 269 can be folded into a hairpin loop which terminates at base 314 with the sequence $5^{\prime}-$ TTCTTT. This conformation resembles a transcription terminator (Rosenberg \& Court, 1979), which may play a role in the regulation of transcription of the lys gene.

Analysis of the nucleotide sequence proximal to the $5^{\prime}$ end of the E9lys gene did not reveal any promoter-like sequences, consistent with our earlier finding that significant expression of the lys gene is dependent upon the SOS promoter (Chak \& James, 1986). Experiments with promoter probe vectors had demonstrated the activity of a promoter in the ClaI-EcoRI fragment which transcribed towards the ClaI site (Chak \& James, 1986). In the absence of any indications of any other gene being encoded by this fragment, it was suggested that this may represent the E9imm gene promoter. This proposal meant that the transcription of the E9imm gene was in the opposite orientation to that of the lys gene present in the $640 \mathrm{bp} \mathrm{ClaI-EcoRI} \mathrm{fragment} \mathrm{(Chak} \mathrm{\&}$ James, 1986). The nucleotide sequencing data reported here do not support this conclusion; however, they clearly show the presence of a complementary sequence to the consensus -10 promoter sequence TATAAT (Rosenberg \& Court, 1979) commencing at base 40 , and a complementary sequence to a -35 promoter sequence TTGTAA (Rosenberg \& Court, 1979) commencing at base 60 (Fig. 3). The activity of this presumptive promoter transcribing in the 
opposite orientation to the E9imm and lys genes would explain our earlier findings. A possible ORF transcribed by this promoter commences at base 29 . Nucleotide sequencing of clones containing DNA sequences upstream of the ClaI site will be required to determine whether this ORF translates into a protein of any significant size and whether it overlaps the colicin E9 coding sequence.

The 760 bp EcoRI-Pvul fragment. There are two ORFs in the $760 \mathrm{bp} E c o$ RI-PvuI fragment of the ColE9 plasmid which could encode the E5imm gene. They both terminate at base 1062 and commence from base 733, or from base 811 . Both ORFs are consistent with our observation that insertion of Tn 1000 between 100 and 350 bp to the right of the EcoRI site of pKC67 inactivates the E5imm gene. In view of the presence of a reasonable -10 (TTATAT) promoter sequence at base 769, and the fact that the E5imm gene has its own promoter, we conclude that the ORF from base 811 to base 1062 encodes the E5imm gene. A search for a -35 promoter sequence did not reveal any strong candidates, with the possible exception of the TTGAAC sequence starting at base 749 . Although the distance between this presumptive -35 sequence and the -10 promoter sequence is only 8 bp compared with the optimal spacer length of $17 \mathrm{bp}$ (Stefano \& Gralla, 1982), a similar value was observed for the presumptive E8imm gene promoter found on the ColE3-CA38 plasmid (Lau et al., 1984). The presumptive E5imm gene encodes a protein of 83 amino acids which shows little homology to any of the $\mathrm{E}$ colicin immunity proteins that have been sequenced. The AT-rich region of DNA downstream of the presumptive E5imm gene can be folded into a hairpin structure as was previously reported for the region downstream of the E8imm gene (Lau et al., 1984).

The ORF which encodes the E5lys gene present in this fragment is presumably located between bases 1160 and 1303 (Fig. 3). This ORF when translated would encode a protein of 47 amino acids, showing remarkable homology to the lys genes which have previously been sequenced (Fig. 5). The nucleotide sequence proximal to the $3^{\prime}$ end of the lys gene is identical to that found downstream of the $3^{\prime}$ end of the lys gene on the ColE2-P9 plasmid and includes a classic rho-independent transcription terminator (Cole et al., 1985). We have not been able to isolate any $\mathrm{Tn} 1000$ inserts in this gene, presumably due to the absence of any resulting phenotypic alteration.

\section{RNY analysis}

It was reported by Morlon et al. (1983), and by Cole et al. (1985), that E colicin genes are quite unusual in that they contain a high proportion of 'rare' codons. Our data from pKC124 are consistent with this observation, but if an analysis of the nucleotide sequences of immunity and lysis genes is made by the method of Shepherd (1981), then some interesting differences are observed. In an investigation of the distribution of RNY codons in a variety of genes, Shepherd observed that the correct reading frame of the genes contains a higher number of RNY codons than the other two possible reading frames. A relatively small number of exceptions to this rule have been reported (Shepherd, 1984). It is therefore perhaps surprising that all the E colicin lys genes which have been sequenced, including that encoded by the CloDF 13 plasmid, do not obey Shepherd's rule (Table 1). In contrast, the ColA lys gene and the $S$ lysis gene of phage $\lambda$ do obey Shepherd's rule. The lysis gene $(E)$ of phage $\phi \times 174$ was previously reported to also be an exception to Shepherd's rule (Shepherd, 1984). The $S$ gene of $\lambda$, which has been reported to be functionally equivalent to the colicin E1 lys gene (Suit et al., 1983), is at least twice the size of any of the E colicin lys genes. All of the E colicin immunity genes follow Shepherd's rule, although the El imm gene is rather unusual in having a similar number of RNY codons in all three reading frames. The Elimm gene also has a very low GC ratio when compared to all the other E colicin genes. The ColAimm gene, however, is also an exception to Shepherd's rule.

It has been proposed that an RNY codon message could have been the basis of a primitive, comma-free, genetic code which has since evolved by the acquisition of the ability to use start and stop codons to delimit genes (Shepherd, 1981). One consequence of an RNY message is that a frameshift which results in the highest number of RNY codons being found in reading frame 3, when the correct reading frame is frame 1 , will result in a higher than average number of 
Table 1. RNY codon analysis

\begin{tabular}{|c|c|c|c|c|c|c|}
\hline \multirow[b]{2}{*}{ Gene } & \multirow[b]{2}{*}{$\begin{array}{l}\text { No. of } \\
\text { codons }\end{array}$} & \multirow{2}{*}{$\begin{array}{c}\text { GC ratio } \\
(\mathrm{mol} \%)\end{array}$} & \multirow{2}{*}{$\begin{array}{l}\text { Total } \\
\text { RNY }\end{array}$} & \multicolumn{3}{|c|}{ RNY codons } \\
\hline & & & & RF1 & RF2 & RF3 \\
\hline $\begin{array}{l}\text { E1lys } \\
\text { E2lys }\end{array}$ & $\begin{array}{l}45 \\
48\end{array}$ & $\begin{array}{l}46.4 \\
43.05\end{array}$ & $\begin{array}{l}29 \\
36\end{array}$ & $\begin{array}{l}10 \\
13\end{array}$ & $\begin{array}{l}7 \\
4\end{array}$ & $\begin{array}{l}12 \\
19\end{array}$ \\
\hline E3lys & 48 & 43.05 & 36 & 13 & 4 & 19 \\
\hline Eslys & 47 & $44 \cdot 4$ & 36 & 14 & 5 & 17 \\
\hline E9lys & 26 & 35.8 & 18 & 7 & 2 & 9 \\
\hline ColA lys & 51 & $43 \cdot 6$ & 39 & 25 & 3 & 11 \\
\hline Clo lys & 49 & $46 \cdot 7$ & 34 & 13 & 5 & 16 \\
\hline$\lambda S$ & 107 & $48 \cdot 1$ & 82 & 41 & 17 & 24 \\
\hline$\phi \times 174 E$ & 91 & 47.8 & 61 & 14 & 12 & 35 \\
\hline E1 imm & 113 & 28.6 & 72 & 25 & 23 & 24 \\
\hline E2imm & 86 & 39.8 & 69 & 30 & 22 & 17 \\
\hline E3imm & 85 & 33.7 & 69 & 33 & 23 & 13 \\
\hline E5imm & 83 & $35 \cdot 7$ & 62 & 28 & 12 & 22 \\
\hline E8imm & 85 & $35 \cdot 7$ & 69 & 38 & 22 & 9 \\
\hline E9imm & 86 & $37 \cdot 1$ & 69 & 29 & 21 & 19 \\
\hline ColAimm & 179 & $34 \cdot 1$ & 138 & 51 & 23 & 64 \\
\hline Cloimm & 85 & 34.5 & 68 & 32 & 20 & 16 \\
\hline
\end{tabular}

hydrophobic residues in the protein structure (Shepherd, 1984). It will be of interest to see how many other proteins which interact with membranes, like the E colicin lys genes, the ColAimm gene, and less so the ColElimm gene, will be exceptions to Shepherd's rule.

\section{Evolutionary relationships between $E$ colicin operons}

Our sequence data support a very close evolutionary relationship between the E9imm gene, the E2imm gene, and the E8imm gene present on the ColE3-CA38 plasmid. This predicts that the amino acid sequence of the three colicin structural genes will also be very similar (thus far only the colicin E2 gene has been sequenced: Cole et al., 1985). Changes in the nucleotide sequence of an ancestral colicin gene, tied closely with parallel changes in the homologous immunity protein gene, have presumably resulted in the evolution of a group of related bacteriocins which are only inactivated by their homologous immunity proteins. A comparison of the differences in amino acid sequence of these three colicins and their immunity proteins may be a particularly valuable system for the study of molecular recognition between proteins.

One particularly interesting conclusion from our sequencing and transposon mutagenesis data is that a functional $\mathrm{E}$ colicin lys gene need only be 26 amino acids long. The primary function of an E colicin lys gene product is not fully understood, although it is believed to interact in some way with the enzyme phospholipase A to achieve colicin secretion from the host cell (Pugsley \& Schwartz, 1984). MC-induced cell lysis, as observed in the laboratory, may refiect an extreme level of induction of colicin operons and therefore may have little real relevance to the process of normal colicin secretion by a colicinogenic $E$. coli cell. The introduction of an artificial ochre stop codon 9 amino acids from the C-terminus of the pColE2 and the pColE3 lys genes did not significantly reduce the MC sensitivity conferred on $E$. coli by the modified lys genes (Toba $e t$ al., 1986). It has been suggested that the N-terminal 19 amino acids of the pColE2 and pColE3 lys genes are signal sequences which direct the protein to the correct membrane location before cleavage (Cole et al., 1985). This leaves 19 amino acids of these two lys gene products to interact with phospholipase A and result in colicin release from the cell. Our data show that the E9lys gene encodes a protein of only 26 amino acids and that it lacks the cleavage site present in the pColE2 and pColE3 lys genes. This 'truncated' lys gene is obviously still capable of promoting cell lysis (Fig. 2), and we are investigating its ability to promote colicin secretion. Site-directed mutagenesis of the E9lys gene and the synthesis of oligonucleotides which encode mutant forms of the E9lys gene will be invaluable in furthering our understanding of the processes of colicin secretion and cell lysis. 
We are grateful to Kin Chak for helpful discussions of this work, to Colin Clarke for introducing us to the concept of RNY analysis of nucleotide sequences and to Jill Debbage and Lynne James for excellent technical assistance. Dick Barker and Mark Jarvis are employees of the Agricultural Genetics Corporation, Cambridge, UK.

\section{REFERENCES}

BARKeR, R. F., IdLeR, K. B., Thompson, D. V. \& KEMP, J. D. (1983). Nucleotide sequence of the TDNA region from the Agrobacterium tumefaciens octopine $\mathrm{Ti}$ plasmid pTil5955. Plant Molecular Biology 2, 335-350.

BIRNBoIM H. C. \& Doly, J. (1979). A rapid alkaline extraction procedure for screening plasmid DNA. Nucleic Acids Research 7, 1513-1523.

CHAK, K.-F. \& JAMES, R. (1984). Localization and characterization of a gene on the ColE3-CA38 plasmid that confers immunity to colicin E8. Journal of General Microbiology 130, 701-710.

ChaK, K.-F. \& JAMES, R. (1985). Analysis of the promoters for the two immunity genes present in the ColE3-CA38 plasmid using two new promoter probe vectors. Nucleic Acids Research 13, 2519-2531.

CHAK, K.-F. \& JAMES, R. (1986). Characterization of the ColE9-J plasmid and analysis of its genetic organization. Journal of General Microbiology 132 , 61-71.

Cole, S. T., Saint-Joanis, B. \& Pugsley, A. P. (1985). Molecular characterisation of the colicin E2 operon and identification of its products. Molecular and General Genetics 198, 465-472.

COOPER, P. C. \& JAMES, R. (1984). Two new E colicins, E8 and E9, produced by a strain of Escherichia coli. Journal of General Microbiology 130, 209-215.

Di Masi, R. D., White, J. C., Schnaitman, C. A. \& BRADBEeR, C. (1973). Transport of vitamin $B_{12}$ in Escherichia coli: common receptor sites for vitamin $B_{12}$ and the $E$ colicins on the outer membrane of the cell envelope. Journal of Bacteriology 115, 566-573.

GUYER, M. S. (1978). The $\gamma \delta$ sequence of $\mathbf{F}$ is an insertion sequence. Journal of Molecular Biology 126 , $347-365$.

JAKES, K. S. \& ZiNDER, N. D. (1984). Plasmid ColE3 specifies a lysis protein. Journal of Bacteriology 94, 691-699.

KoNISKY, J. (1982). Colicins and other bacteriocins with established modes of action. Annual Review of Microbiology 36, 125-144.

Lau, P. C. K., Rowsome, R. W., Watson, R. J. \& VISENTIN, L. P. (1984). The immunity genes of colicin E2 and colicin E8 are closely related. Bioscience Reports 4, 565-572.

LAWRENCE, G. M. P. (1984). Characterization of the ColE8 plasmid. PhD thesis, University of East Anglia, Norwich, UK.

LAWRENCE, G. M. P. \& JAMES, R. (1984). Characterization of the ColE8 plasmid, a new member of the group E colicin plasmids. Gene 29, 145-155.

Maniatis, T., Fritsch, E. F. \& SambrooK, J. (1982).
Molecular Cloning: a Laboratory Manual. Cold Spring Harbor, NY: Cold Spring Harbor Laboratory.

MaXAm, A. M. \& Gilbert, W. (1980). Sequencing endlabelled DNA with base specific chemical cleavages. Methods in Enzymology 65, 499-560.

MILlER, J. H. (1972). Experiments in Molecular Genetics. Cold Spring Harbor, NY: Cold Spring Harbor Laboratory.

Morlon, J., Lloubes, R., Varenne, S., Chartier, M \& Lazdunski, C. (1983). Complete nucleotide sequence of the structural gene for colicin A, a gene translated at a non-uniform rate. Journal of Molecular Biology 170, 271-285.

Pugsley, A. P. \& Schwartz, M. (1984). Colicin E2 release: lysis, leakage or secretion? Possible role of phospholipase. EMBO Journal 3, 2393-2397.

ROSENBERG, M. \& COURT, D. (1979). Regulatory sequences involved in the promotion and termination of RNA transcription. Annual Review of Genetics 13, 319-353.

SHEPHERD, J. C. W. (1981). Method to determine the reading frame of a protein from the purine/pyrimidine genome sequence and its possible evolutionary justification. Proceedings of the National Academy of Sciences of the United States of America 78, 15961600.

SHEPHERD, J. C. W. (1984). From primeval message to present-day gene. Cold Spring Harbor Symposia on Quantitative Biology 47, 1099-1108.

Shine, J. \& Dalgarno, L. (1974). The 3'-terminal sequence of Escherichia coli $16 \mathrm{~S}$ ribosomal RNA: complementary to nonsense triplets and ribosome binding sites. Proceedings of the National Academy of Sciences of the United States of America 71, 13421346.

Stefano, J. E. \& Gralla, J. D. (1982). Spacer mutations in the lac $\mathrm{p}^{\mathrm{s}}$ promoter. Proceedings of the National Academy of Sciences of the United States of America 79, 1069-1072.

SuIT, J. L., FAN, M.-L. J., SABIK, J. F., LABarRe, R. \& LURIA, S. E. (1983). Alternative forms of lethality in mitomycin $\mathrm{C}$-induced bacteria carrying ColEl plasmids. Proceedings of the National Academy of Sciences of the United States of America 80, 579-583.

Toba, M., Masaki, H. \& OHTA, T. (1986). Primary structure of the ColE2-P9 and ColE3-CA38 lysis genes. Journal of Biochemistry 99, 591-596.

WATSON, R., RowSOME, W., TSAO, J. \& VisENTIN, L. P. (1981). Identification and characterization of $\mathrm{Col}$ plasmids from classical colicin E-producing strains. Journal of Bacteriology 147, 569-577. 